\title{
THE BEAST COMPUTER IN BRUSSELS: RELIGION, CONSPIRACY THEORIES, AND CONTEMPORARY LEGENDS IN POST-SOVIET CULTURE
}

\author{
Alexander Panchenko \\ Center for Anthropology of Religion, European University at St. Petersburg \\ Institute of Russian Literature, Russian Academy of Sciences \\ St. Petersburg State University, Russia \\ e-mail: apanchenko2008@gmail.com
}

\begin{abstract}
Conspiracy theory is a powerful explanatory model or a way of thinking, which influences many cultural forms and social processes across the contemporary world. Recent academic research into conspiracy theories provides a set of interpretations ranging from medicalization (social/political paranoids) to the concept of 'popular knowledge' as a specifically postmodern phenomenon. In modern and postmodern societies, conspiracy theories often motivate political action and social praxis, accompany the transformation of institutional and informational networks, and provoke moral panic and changes of identity. The paper deals with the role of conspiratorial motifs and themes in the formation and transmission of what is known as contemporary legend. The discussion of empirical data focuses on apocalyptic narratives about 'the Beast of Brussels'. Proceeding from the memetic approach in folklore studies as well as the concept of emotional communities, I try to show how and why present-day conspiracy theories and practices of conspiratorial hermeneutics are inspired by particular combinations of emotional, moral, and epistemological expectations.
\end{abstract}

Keywords: conspiracy theory, contemporary Christian eschatology, contemporary legend, emotional communities, meme theory, post-Soviet culture, the Beast of Brussels

\section{INTRODUCTION}

When we discuss the problem of the meaning of what we call folkloric texts, we can approach the issue from quite different positions and use a variety of explanatory models. It seems to me, however, that present-day debates on the meaning of folklore generally proceed from two general models which I would call semiotic and memetic. The first one, ranging from structuralism to psycho- 
analysis, implies that every text or theme or tale type possesses its own initial or immanent meaning that might be transformed through time and place but can still be investigated by means of proper analytical tools. The second one that proceeds from the concept of memes or cultural replicators, suggested by British zoologist Richard Dawkins in his book The Selfish Gene (1976), looks at texts and all other units of cultural imitation as essentially meaningless and as acquiring their particular meaning(s) depending on communicative context(s). In this perspective, survival or long historical life of folk narratives and other 'mind viruses' is provided by their adaptive potential or fitness, which, in turn, is related to the properties of human cognition, memory, and emotions rather than rationally understandable information. ${ }^{1}$ A very similar approach was recently elaborated by cognitive scientists of religion, who considered "religious concepts and norms and the emotions attached to them" to be "designed to excite the human mind, linger in memory, trigger multiple inferences in the precise way that will get people to hold them true and communicate them" (Boyer 2001: 329).

Roughly speaking, this point of view means that any folklore item engaged or employed by human beings or communities that will to connect or conflict does not in fact express or project attitudes or meanings but rather parasitizes on individual or collective emotions and cognitive devices that assemblage knowledge and power in a given social context. Our task as folklorists then is not to uncover any substantial structures of meaning related to this or that narrative but to understand which cognitive and/or emotional properties provide its adaptability in numerous contexts of social communication.

In this article, I try to demonstrate how this approach can be applied in the study of contemporary narrative culture, more precisely, of one particular group of motives or themes that combine religious eschatology with present-day conspiratorial thinking and easily migrate from one confessional subculture to another. Prior to the discussion of empirical data, I need, however, to look in more detail at how conspiracy theories are related to contemporary legend and why conspiratorial narratives appear to be so influential in present-day religious culture. Conspiracy theory is a powerful explanatory model or way of thinking, which influences many cultural forms and social processes throughout the contemporary world. Generally defined as "the conviction that a secret, omnipotent individual or group covertly controls the political and social order or some part thereof" (Fenster 2008 [1999]: 1), a conspiracy theory includes a number of principal ideas and concepts that make it adaptable for a broad variety of discourses and forms of collective imagination. Proceeding from the necessity to explain and localize evil as a social and moral category, conspiracy theories produce ethical models that oppose 'us' to 'them', 'victims' to 'enemies', 'heroes' to 'anti-heroes'. At the same time, conspiracy theories are extremely 
teleological; they do not leave any room for coincidences and accidents and explain all facts and events as related to intentional and purposeful activities of 'evil actors'. Quite often, conspiracy theories are grounded in the holistic worldview that leads, in turn, to particular hermeneutic style. Reality is always considered to be deceptive; simple, superficial, and obvious explanations must give place to more complicated intellectual procedures aimed at the disclosure of 'concealed truth'. From this perspective, the concept of mystery appears to be the most powerful element of conspiratorial narratives that operate in both preand postindustrial societies. Recent academic research of conspiracy theories provides a set of interpretations ranging from medicalization (social/political paranoids) to the concept of popular knowledge as a specifically postmodern phenomenon (Hofstadter 1965 [1952]; Wood 1982; Pipes 1997; Marcus 1999; Knight 2000; West \& Sanders 2003; Birchall 2006; Pelkmans \& Machold 2011). It is obvious, however, that social, political, and cultural power of conspiratorial narratives should not be underestimated. In modern and postmodern societies, conspiracy theories often motivate political action and social praxis, accompany transformation of institutional and informational networks, provoke moral panics and changes of identities.

One of the first theoretical explanations for a conspiracy theory (understood here as an epistemological model rather than a form of collective imagination) was suggested by Sir Karl Raimund Popper in the mid-1940s. It reads as follows:

In order to make my point clear, I shall briefly describe a theory which is widely held but which assumes what I consider the very opposite of the true aim of the social sciences; I call it the 'conspiracy theory of society'. It is the view that an explanation of a social phenomenon consists in the discovery of the men or groups who are interested in the occurrence of this phenomenon (sometimes it is a hidden interest which has first to be revealed), and who have planned and conspired to bring it about. This view of the aims of the social sciences arises, of course, from the mistaken theory that, whatever happens in society - especially happenings such as war, unemployment, poverty, shortages, which people as a rule dislike - is the result of direct design by some powerful individuals and groups. This theory is widely held; it is older even than historicism (which, as shown by its primitive theistic form, is a derivative of the conspiracy theory). In its modern forms it is, like modern historicism, and a certain modern attitude towards 'natural laws', a typical result of the secularization of a religious superstition. The belief in the Homeric gods whose conspiracies explain the history of the Trojan War is gone. The gods are abandoned. But their place is filled by powerful men or groups - sinister pressure groups 
whose wickedness is responsible for all the evils we suffer from - such as the Learned Elders of Zion, or the monopolists, or the capitalists, or the imperialists. (Popper 1966 [1962]: 94; cf. Popper 1962: 163).

In fact, the reasoning cited was intended to emphasize Popper's own indeterministic view on society and history. On the other hand, mentioning "the secularization of a religious superstition" and the gods who are 'abandoned', definitely refers to the progressionist conception of "disenchanted world" (in Max Weber's (1989) terms) if not historical determinism itself. It seems that presently we could hardly rely on this conception, especially after so many scholarly debates on desecularization as well as post-secular society (see, e.g., Berger 1999; Habermas 2006; Karpov 2010; Gorski et al. 2012). However, the very issue of how religion and conspiracy theory are related to each other (even if we approach both from the most radical constructionist positions) still deserves discussion.

At first glance it seems likely that anthropology of secularism (if not the theory of secularization itself) provides some explanatory perspectives in this context. One could suggest, for instance, that conspiratorial modes of thinking that are specifically characteristic of modernity are at least partly related to those configurations of private and public, pluralism and monism, belief and knowledge, which are in the core of 'classic' secular societies, and the gods after their return discovered that they have to share the world, to enter into alliances, or to be at war with secret powers and evil conspirators.

However, the very history of pre-secular Europe does not support this hypothesis. Generally speaking, the conspiratorial ideas and themes that became widespread in the period of the so called "persecuting society" (i.e., in the eleventh-thirteenth centuries; see Cohn 2005 [1973]; Frankfurter 2006; Moore 2007 [1987]), did not, despite their religious contexts, essentially differ from the conspiracy theories of the age of secularism. Moreover, we could trace back the genealogy of those themes and motives to more archaic types of agrarian societies. It is possible to recall, for example, the famous discussion of Azande witchcraft by Edward Evans-Pritchard. Proceeding from a story about an old granary that has collapsed, Evans-Pritchard (1976: 23) suggests that the very idea of witchcraft allows for explaining why "two chains of causation intersected at a certain time and in a certain place":

The Zande knows that the supports were undermined by termites and that people were sitting beneath the granary in order to escape the heat and glare of the sun. But he knows besides why these two events occurred at a precisely similar moment in time and space. It was due to the action of witchcraft. If there had been no witchcraft people would have been sitting 
under the granary and it would not have fallen on them, or it would have collapsed but the people would not have been sheltering under it at the time. Witchcraft explains the coincidence of these two happenings. (ibid.)

I would also recall here the concept of 'limited good' formulated in the 1960s by American anthropologist George Foster. According to Foster, peasant societies "view their social, economic, and natural universes - their total environment as one in which all of the desired things in life such as land, wealth, health, friendship and love, manliness and honor, respect and status, power and influence, security and safety, exist in finite quantity and are always in short supply". This means that "apparent relative improvement in someone's position with respect to any 'Good' is viewed as a threat to the entire community" (Foster 1965: 296-297), and every serious crisis endangering life, health or wealth of the group members often results in 'scapegoating', i.e., pursuit of individual(s) considered to be responsible for the imbalance of goods. From this perspective, the genealogy of the present-day conspiracy theories can be discussed not only with regard to the intellectual history of European modernity (see, e.g., Wood 1982) but also as related to social explanatory models typical of archaic agrarian societies.

At any rate, mutual relations between the conspiracy theories and religious imagination require further discussions and investigations by social scientists. These investigations could probably start with how evil is recognized and localized by various cultures and in different social or economic contexts. It is symptomatic that certain contemporary social phenomena and ideological tendencies that we usually label as religious demonstrate, so to speak, a specific valency towards conspiratorial explanatory models. Christian eschatology gives plenty of obvious examples in this context, especially in relation to present-day apocalyptic thinking. In his book dealing with apocalyptic visions in contemporary America and symptomatically titled A Culture of Conspiracy, political scientist Michael Barkun remarks:

Belief in conspiracies is central to millennialism in the late twentieth and early twenty-first centuries. That is scarcely surprising - millennialist worldviews have always predisposed their adherents to conspiracy beliefs. Such worldviews may be characterized as Manichaean, in the sense that they cast the world in terms of a struggle between light and darkness, good and evil, and hold that this polarization will persist until the end of history, when evil is finally, definitively defeated. (Barkun 2003: 1)

It seems then that religion in contemporary societies is not substituted by conspiracy theories, as it has been suggested by Popper, but absorbs them or is 
absorbed by them. Not accidentally, many religious subcultures today promote not only conspiracy theories, but also a larger group of parascientific beliefs and practices as well as key themes and motives of urban legends - UFO beliefs, spiritual healing, astrology, alternative history, and so on (see Barkun 2003; Birchall 2006). In his book, Barkun goes further to suggest that we presently deal with "a new and growing form of millennialism", which can be called improvisational:

Unlike earlier forms, which elaborated themes from individual religious or secular traditions, improvisational millennialism is wildly eclectic. Its undisciplined borrowings from unrelated sources allow its proponents to build novel systems of belief. (Barkun 2003: xi)

In terms of the history of religious ideas, this shift of religious thinking can be interpreted as a specifically post-secular condition, in which successful religions might and even should "draw upon science for their metaphors and inspiration" (Bainbridge 1993; Rothstein 2004), thus claiming for their own positions within socially valued systems of knowledge production. However, it is still not clear why these or those types of stigmatized or rejected knowledge, including conspiracy theories, are particularly attractive to religious audiences. What makes conspiratorial narratives and themes so popular and adaptable for various groups of believers throughout contemporary world?

\section{THE BEAST OF BRUSSELS: CONSPIRATORIAL NARRATIVES AND APOCALYPTIC IMAGINATION}

From this perspective, I would like to focus on a particular group of conspiratorial/eschatological themes of popular imagination, which make a certain impact on religious cultures in present-day Russia, Ukraine, and some other post-Soviet states, and at the same time have an interesting and analytically important history. It is necessary then to start with historical observations.

The 1970s witnessed the rise of apocalyptic fears and expectations in the United States. The wave of eschatology was mainly related to ideologies of the so called Christian ultraconservatives or the New Christian Right. Although this last term can be used in various ways (sometimes to point to those religious activists who take part in political life), it generally refers to the New Protestants - evangelical Christians oriented towards religious fundamentalism (i.e. literal interpretation of the Bible) and extremely conservative views on politics and society. The movement of religious conservatives involves an essential part 
of Baptist and Pentecostal congregations in the United States as well as numerous non-denominational evangelical groups. Besides social conservatism and certain anti-liberal views, the ideologies of the New Christian Right proceed from clearly formulated eschatological expectations. The mentioned apocalyptic wave of the 1970s was supported not only by theological writings and public sermons. In fact, it gave rise to particular eschatological genres including prophetic visions of the near future as well as apocalyptic fiction and movies telling about terrible events of the 'end times' (Boyer 1992: 115-290; Shuck 2005). In the last decades, these genres of religious fiction were mainly represented by The Left Behind novels and movies by evangelical writers Tim LaHaye and Jerry Jenkins (the first novel in the series was released in 1995, and its film version in 2001). However, the tradition started at the beginning of the 1970s with, for example, low budget evangelical prophecy films produced by Donald W. Thompson:

His four-part series included A Thief in the Night, A Distant Thunder, Image of the Beast, and The Prodigal Planet. The four films, especially A Thief in the Night, dramatized the End-Times scenario familiar to evangelical audiences and transformed it into a powerful conversion tool. (Shuck 2005: 7)

It is necessary to remark here that the aspects of apocalyptic future of the humankind are discussed by evangelical Christians in more detail than, for example, by Russian Orthodox believers, who never paid too much attention to the literal interpretation of the Bible. Attempts to systematize all the eschatological prophesies found in the Old and especially in the New Testament allowed the New Protestants to create several doctrines that describe the future of the mankind before the end of the world and the Last Judgment with some differences. Without going into details of these debates, I have to mention that the arguments mainly deal with the sequence of events related to the Millennial Kingdom of the righteous (Rev. 20), the Great Tribulation described in the Olive discourse by Jesus Christ (Matthew 24: 3-44; Mark 13: 3-33; Luke 21: 5-36), and the Rapture of the righteous (or the true church) to heaven (Paul's 1st epistle to Thessalonians 4: 14-18). According to the doctrine of Pretribulational (dispensational) Premillennialism, it will be Christ who comes back and performs the Rapture. Then the Great Tribulation will come, and the Millennium will start after it has ended. The doctrine of Posttribulational Premillennialism insists that the sequence of apocalyptic events will start with the Great Tribulation, and only those who survive it with true faith and righteousness will take part in the Millennial Kingdom (Boyer 1992: 80-112; Barkun 2003: 41-45; Shuck 2005: 30-41; Fenster 2008 [1999]: 205-206). 


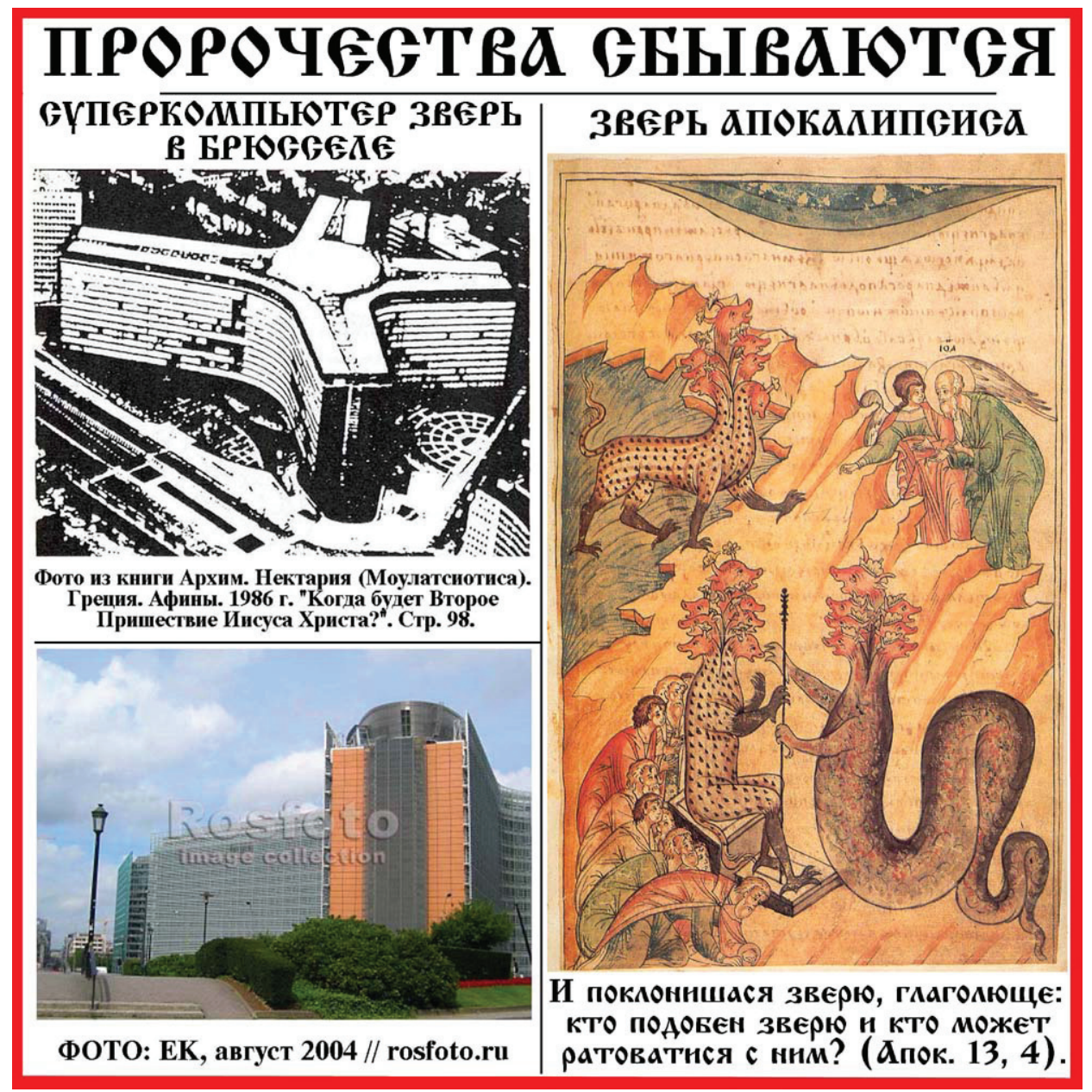

Figure 1. A Russian Orthodox leaflet: "Prophecies are coming true: The Beast supercomputer in Brussels" (http: / / www.zaistinu.ru / articles / ?aid=623).

At any rate, attempts to discover the signs of the Last Times ${ }^{2}$ in the prophetic culture of the New Christian Right did not avoid the discussion of current political events. Special attention in this context was paid to the foundation of the state of Israel in 1948. Although the details of the role to be played by the Jews in the Last Times can be debated by various groups of the fundamentalist Christians, all of them agree that "Israel is being gathered for conversion and redemption" (to use the formulation by conservative Pentecostals in Russia). ${ }^{3}$ 
At the same time, geopolitical scenery of the last decades of the Cold War provided American evangelicals with a spacious field for apocalyptic fantasies about the Antichrist, his allies and forerunners, appearance, activities, and so on. The old Protestant tradition of thinking about the Holy See and Roman Catholicism as somehow related to apocalyptic imagery was now supported by a new political agenda. The movement that started with the Rome agreement of 1957 and led to the foundation of the European Union in 1992 was interpreted by many ultraconservative Christians in the same eschatological context - as preparations for the coming of the Antichrist (Boyer 1992: 273-277). The union of European nations was considered to be the new incarnation of the Roman Empire or even the ten-horned beast from the Revelation (13) and Daniel's vision (7: 23); this was discussed when Greece became the tenth member of the Common Market (Boyer 1992: 277). On the other hand, American Christian fundamentalists were generally suspicious of international political organizations with global authority (the United Nations and others). This particular anti-globalism was one of the leading themes of American apocalyptic narratives of the 1970 s.

Another eschatological theme that was getting more and more powerful was the phobia of certain information technologies: first television that could be used by demonic forces and the Antichrist himself, and later on also computers (Boyer 1992: 106-107, 279-281). Those fears were related to the idea of total control and manipulation of all the human beings from the side of hidden and mysterious forces that use powerful and ubiquitous technical devices. In the 1970 s, this image of the 'surveillance society', to use the term by the Canadian sociologist David Lyon (1994; cf. Shuck 2005: 119-128), was discussed and interpreted with special attention in 1984, the famous dystopian novel by George Orwell. This literary text, although being purely secular, was read by many Christian conservatives in terms of their own apocalyptic prophesies and could be regarded by them as one of the signs of the Last Times coming soon or even as a precise description of the near future of the mankind. It is possible, however, to talk about more general social contexts that bring together the literary genre of dystopia and the conspiratorial eschatology of the twentieth century. According to an astute observation by Maria Akhmetova, apocalyptic narratives that became widespread in Russia in the 1990s and 2000s often depict the future tyranny of the Antichrist "in correspondence with the dystopian novel, a literary genre that was taken by late Soviet and post-Soviet readers as describing totalitarianism of the twentieth century" (Akhmetova 2010: 195). I would say, however, that it is not only totalitarianism (or specific Soviet experience) that influences both dystopian novels and apocalyptic narratives; the very image of the 'surveillance society' could be related to global processes of modernization, 
urbanization, and formation of consumer society. It seems that collective fears associated with anonymity, loss of social status, and control over one's own body are stimulated by those global factors and, in particular, represented by dystopian and apocalyptic narratives.

Fears and expectations of this kind seem to constitute the initial context for the story of the Beast computer that I am talking about. In the late 1970s, Christian prophecy writers in the United States started repeating a rumor "that a giant supercomputer is being created in Brussels for the purpose of taking over the world's banking system and creating a cashless economic system, as was prophesied in Revelation" (Fuller 1995: 181). Its particular sources can be debated, but it seems that the "canonic' version of the story was invented in 1975 by a certain person from the Southwest Radio Church, a non-denominational evangelical radio broadcast program in Oklahoma City. ${ }^{4}$ The most likely authors of the story were pastors David Webber (1931-2004) and Noah Hutchings (1922-2015), who later on published a special book titled Computers and the Beast of Revelation (1986). In 1975, "the Southwest Radio Church reported that this supercomputer, dubbed 'the Beast,' would link banks throughout the world and gradually force 'a socialistic economic leveling and a new money system in the 1980s.' In the same year Colin Deal (a prophecy writer especially known for his bestseller Will Christ Return by 1988? 101 Reason Why) informed his readers that 'Common Market leaders during a crisis meeting in Brussels, Belgium, were introduced to the 'Beast,' a gigantic computer that occupies three floors of the Administration Building at the Common Market Headquarters. The computer is capable of assigning a number to every person on earth in the form of a laser tattoo. Then, through infrared scanners, this invisible tattoo would appear on a screen"' (Fuller 1995: 181).

It is obvious that the rumor, on the one hand, proceeded from the images and ideas of Revelation 13, and, on the other, hinted at the commercial use of barcoding that in the mid-1970s was getting popular in the United States and later in Europe (the first item with a barcode was a pack of Juicy Fruit chewing gum sold in Ohio on June 26, 1974). Quite soon, the story about the Beast of Brussels became popular enough in the United States without any references to particular Christian authors. Its main version that can still be found on the web reads as follows:

Dr. Hanrick Eldeman, Chief Analyst of the Common Market Confederacy in Brussels, has revealed that a computerized restoration plan is already under way to straighten out world chaos. A crisis meeting in early 1974 brought together Common Market leaders, advisers and scientists at which time Dr. Eldeman unveiled "the Beast". The Beast is a gigantic three story computer located in the administrative building of the headquarters of 
the Common Market. That monster is a self-programming computer that has more than one hundred sources distributing entries. Experts in programming have perfected a plan that will handle by computer all of the world's trade. This master plan would imply a system of digital enumeration of each human being of the earth. Thus the computer would give each inhabitant of the world a number to be used for each purchase or sale, removing the problem of present credit cards. This number would be invisibly tattooed by laser, either on the forehead or on the back of the hand. This would establish a walking credit card system. And the number could be seen only through infrared scanners, installed in special verification counters or in business places. Dr. Eldeman pointed out that by using three entries of six digits each, every inhabitant of the world would be given a distinct credit card number. ${ }^{5}$

In the 1980s, the narrative gained international popularity and was translated into European languages. One of the books that especially promoted the rumor was the bestseller titled When Your Money Fails, by Mary Relfe, a Christian writer from Alabama. However, before discussing the book in more detail, it is necessary to point out the immediate political context of the story about the Beast of Brussels.

The mentioning of a crisis meeting in early 1974 in the narrative was not accidental. The fact is that 1973 witnessed the first (and still the hugest) global oil crisis. Eleven days after the beginning of the Yom Kippur (or October) war between Egypt, Syria, and Israel, the OPEC states announced suspension or shortage of oil supply for the United States and their allies supporting the Jewish state. Soon the oil prices grew four times, from 3 to 12 dollars per barrel. On November 6, 1973, the ministers of foreign affairs of the Common Market met in Brussels and signed a declaration stating that Israel had to implement the 242 resolution of the UN Security Council, i.e., to quit the Sinai Peninsula and the Golan Heights. Finally, those political debates led only to a split in NATO and the maintenance of high oil prices, so the state that benefited was the Soviet Union; the crisis laid the foundation for the 'Brezhnev prosperity'. At the same time, the 1973 war stimulated a new deterioration of relations between the United States and the USSR. When the Israeli army launched a counteroffensive and forced a crossing over the Suez Canal, Brezhnev threatened that the USSR would go into action directly and the United States announced alert of their nuclear forces.

For American evangelicals, the events of the October war directly corresponded with their apocalyptic prophecies and expectations. One of the main themes of the American prophecy narratives of the early 1970s was a future catastrophic war between Israel, Arab states, and the USSR. According to the 
political predictions made by one of the most famous American prophecy writers, Hal Lindsey, in 1970, the following 'players' will dominate the geopolitical scene in the Last Times:

Russia (equivalent to the 'Gog' peoples of Ezekiel), which is developing a vast army and confederacy and will march on Israel; the Arabs, who will join with Africans and be led by Egypt in a march on Israel; China and a vast 'Oriental horde' of more than 200 million soldiers; and the European Community, which will form a new Roman Empire and dominate the world under its leader, the Antichrist. (Fenster 2008 [1999]: 201)

However, Israel was not defeated by Arabs, the world economy did not collapse, the third world war did not start, and the story about the Beast of Brussels started living its own life, acquiring new meanings and contexts. From this perspective, its Russian biography appears to be quite interesting.

The narrative attempted to reach its Russian audience several times. As far as I know, all the Russian translations of the story were related to the book When Your Money Fails: The "666 System" Is Here (1981), by an evangelical writer and founder of the League of Prayer, Mary Stuart Relfe (1916-2011), who lived in Montgomery, Alabama. Proceeding from the idea that the number 666 was penetrating all realms of everyday life in America (the number was found even on sections of floor tiles and shirt labels), Relfe paid special attention to the development of international banking and spread of debit cards that would, she thought, be the principle device of the economic enslaving of the mankind. The story about the Beast computer and Dr. Eldeman was repeated in the book several times (Relfe 1981: 37, 42-46). Moreover, its readers learned that the "little 'Beast of Brussels' was giving way to the real Beast of Luxembourg, the most gigantic Computer Complex in the world, due to completion in 1980" (Relfe 1981: 46). Among other signs of the future reign of the Antichrist, she pointed to the rise of various international organizations, including the World Bank, the World Health Organization, the International Monetary Fund, and others. Some parts of the book focused on the future apocalyptic role of the Soviet Union, which was still believed to be the homeland of the 'Gog' peoples of Ezekiel. To prove that Russia would indeed be the army of horsemen that would come "in the latter years... against the mountains of Israel" (Ezekiel 38: 8), Relfe reprinted in her book a 14-kopek stamp "10 years of the First Cavalry", issued in the USSR at the beginning of 1930. According to Relfe, the stamp picturing armed horsemen with a red banner and the map of the Black Sea region with the cavalry raids marked, "prophetically commemorated" the coming invasion of Russians of Israel (Relfe 1981: 182-183). 
However, all those prophecies did not embarrass one of the first Russian translators of the story about the 'Beast of Brussels', a professor of the Russian language and literature at the University of South Alabama, Pavel Vaulin (1918-2007; see Aleksandrov 2005: 92). Vaulin was a Russian émigré, taken prisoner during the Soviet-Finnish War. After the end of the Second World War, he managed to escape from Finland to Sweden and later on to the United States. There he soon joined the radical religious and nationalistic wing of the Russian diaspora. In 1981, Vaulin translated the introductory part of When Your Money Fails and published it (without references to the original) in his Russian-language journal Niva ([Vaulin] 1981).

Another translation of the same part was prepared independently by either Russian Baptists or Old Believers in America and reached Russia in the late 1980s. A handwritten version of this text was discovered among the manuscripts left behind by an Old Believer from the Urals in 1989 (Ageeva 1997: 11, 16; Soboleva 1997; Pokrovskiy \& Zolnikova 2002). In the same year, the same text was printed in the almanac Put' Spaseniia (The Way of Salvation) published by Russian Old Believers in Oregon ([Tayson V.] 1989). The publication mentioned the author of the translation (a V. Tayson) as well as its sources. The latter included (besides When Your Money Fails) another book by Relfe published in 1982 as well as publications by Australian evangelical missionary Don Stanton (1977) and American Christian writer Willard Cantelon (1973). Yet, it seems that When Your Money Fails was the principal source for the translation. Later on, in 1993, the same text was published by a Russian Baptist publishing house situated in Sochi (Tayson 1993). Although the very name Tayson does not sound Russian, it is possible that the translator was another Russian émigré, Vera Tayson, who in the 1980s was employed as a translator and proofreader by the Russian language newspaper Nashi Dni (Present Days) published by the Pacific Coast Association of Slavic Baptist Churches in Sacramento. ${ }^{6}$ It seems then that this translation had been initially prepared by Russian Baptists in America in the mid-1980s but was also publicized by global networks of the Old Believers.

At any rate, the story about the 'Beast of Brussels' penetrated the borders of the USSR already in the second half of the 1980s. However, the mass spread of the legend in post-Soviet Russia was stimulated not only by the Old Believers' manuscripts and Baptist publications. In September 1991, the head of the publicist department in the journal Nash Sovremennik (Our Contemporary), Sergey Fomin, published a selection of apocalyptic 'prophecies about the destiny of Russia' (Fomin 1991). Later, this selection became part of a huge volume entitled Rossiya pered vtorym prishestviem (Russia before the Second Coming) and edited by Fomin as well. The volume was published repeatedly in Russia in the 1990s and 2000s. Both the 1991 collection and the later separate edi- 
tions included a letter written by monk Antoniy Chernov who at that time lived in the UK and was a member of the 'old calendarist' Genuine Orthodox Church of Greece (Matthewite Synod). The letter (Fomin 1991: 128) included the legend about the 'Beast of Brussels' (quoting the translation by Tayson) and informed its readers about the coming reign of Antichrist, the Jewish pseudoMessiah who had been already born in Israel. This last part of the text was openly anti-Semitic and clearly contradicted pro-Zionistic ideologies of American Evangelical millennialism, so it was obviously borrowed from other (most likely Greek Orthodox) sources. Finally, another independent translation of the story about the Beast computer was printed also in 1991 in the radical monarchist newspaper Zemshchina published in Moscow by the association Khristianskoe Vozrozhdenie (Christian Revival).

It seems that the principal mediators between American evangelical millennialism and post-Soviet high-tech eschatology were Orthodox Greeks. It is quite likely that official religious affiliation of Antoniy Chernov affected the themes of his apocalyptic prophecies. It is worth mentioning that the late 1980s witnessed a moral panic among Orthodox Greeks, the panic being related to the implementation of the Schengen Treaty. The Greek government had signed it in 1992 , but the national parliament ratified it only five years later. The principal 'anti-globalist' argument against the treaty from the side of Orthodox activists was the change of national passports for universal identification cards. The latter in particular were considered to be 'marks of Antichrist'. An additional stimulus for the panic was provided by a public discussion of whether the cards should have indication of the holders' religious affiliation on them (see Molokotos-Liederman 2003). The rumors about the 'Beast of Brussels' related to the panic were promoted not only by small and marginalized 'old calendarist' churches but also, for example, the Greek Orthodox monks from Mount Athos. The book by Relfe, which appeared to be extremely popular at least in some Athos monasteries, was translated into Greek in the mid-1980s (Meletiy 2001: 5-9). In 1987, an Athos monk, Paisios Eznepidis (1924-1994, known also as venerable elder Paisios of the Holy Mountain and canonized in 2015 by the Ecumenical Patriarchate of Constantinople), wrote a pamphlet titled Signs of the Times, 666, which said, in particular:

The secular spirit of contemporary 'freedom', lack of respect to the Church of Christ, to those elders, parents, and teachers who possess the fear of God mask spiritual enslavement, confusion, and anarchy that leads people into a dead end, to spiritual and physical catastrophe. The perfect system of 'convenient cards' and computer security also masks the global dictatorship, the reign of the Antichrist. [...] And all that goes on when the signs are so evident, when the computer 'Beast' in Brussels has nearly 
swallowed up all the countries. Cards, IDs, 'marks'-what do they mean? [...] After the introduction of cards and IDs and 'computer dossiers' they will try to introduce marks. And they will talk on TV how people steal somebody else's cards and get cash. And, on the other hand, they will advertise a 'perfect system'-invisible laser marks in hands and foreheads with 666, the name of the Antichrist. ${ }^{7}$

The popularity of this text and some other writings of this kind by the Athos elders among late Soviet and post-Soviet Orthodox believers seem to account for the 'explosive' transmission of the Russian versions of the story about the Beast of Brussels and Dr. Eldeman at the beginning of the 1990s (see Akhmetova 2010: 146-148). Soon this narrative became a part of the 'conspiratorial canon' shared by radical Orthodox groups protesting against barcodes, individual taxpayer numbers, and electronic cards (see Verkhovskiy 2003: 73-94; Serzhantov 2007-2008; Beglov 2014: 123-126; Russele 2015). Moreover, this very story served as a sort of a narrative foundation or even a trigger for the moral panic that influenced theological and ideological discussions in many religious communities, including the Russian Orthodox Church of the Moscow Patriarchate, the latter having to consider the problem of the individual taxpayer and social security numbers as well as passports with electronic chips at the highest levels of hierarchy (Russele 2015). At the same time, the legend was shared by radical Orthodox groups in Ukraine, Byelorussia, and Kazakhstan, as well as some Pentecostal and Baptist congregations. Here, the fears of computers, barcodes, and individual numbers were largely supported by anti-Western sentiments and ideologies. The Beast of Brussels now was considered to be a part or even the center of apocalyptic conspiracy targeted at Russia (identified here as the former Soviet Union rather than present-day Russian Federation) and the Orthodox belief. Unlike American evangelicals, the post-Soviet supporters of the legend sometimes interpreted it with respect to anti-Semitic beliefs, i.e., as a part of the global Jewish conspiracy.

\section{CONCLUSION}

What conclusions can be drawn from this story? Obviously, it is not unique or absolutely novel in a broad historical context. Themes of count, manipulation of individuals, and total control upon mankind by evil and hostile forces before the end of the world penetrate the history of Christian eschatology. The image of bodily marks inspired by Revelation 13 can be observed in many religious and cultural contexts. American evangelicals and present-day Russian Orthodox 
believers feared laser tattoos inscribed on the body by the Beast of Brussels; Russian nineteenth-century peasants refused vaccination considering it to be 'marks of the Antichrist'.

At the same time, some aspects of the history of the legend about the Beast of Brussels and its intercultural migrations seem to be relatively novel and deserve special attention. Firstly, it brings us back to the memetic approach in the study of contemporary legend. Its international transmission as well as de- or re-contextualization gives one more example of the 'virus' spread of 'cultural replicators' (Oring 2014a, 2014b). This means that we can talk of moral panics inspired by particular conspiratorial narratives as 'cultural epidemics' or "emotional snowballing - runaway selection for emotional content rather than for information" (Heath \& Bell \& Sternberg 2001: 1040). Secondly, this particular text seems to be a part of a broader conspiratorial (meta)narrative, which appeared to be equally valid for quite different religious ideologies and cultures. The same package of eschatology of control and manipulation contains, for example, religious homophobia, the unexpected and at the same time extremely rapid spread of which in present-day Russia could be related to the same American evangelical tradition. Another prophecy writer of the early 1970s, a Pentecostal pastor David Wilkerson (1931-2011), for example, combined in his major work, The Vision (1973), predictions about 'new global economic order' and laser tattoos with the image of future 'moral landslide':

The most gripping images of America as Sodom appeared in the muchreprinted prophecy books of the Assemblies of God evangelist David Wilkerson. In contrast to most prophecy interpreters, Wilkerson in The Vision reported verbatim communications from God foretelling a coming "moral landslide" of "nudity, perversion, and a flood of filth." Television networks will show bare-breasted women; churches will feature nude dancing; "wild, roving mobs of homosexual men" will attack unsuspecting victims openly on the streets. (Boyer 1992: 234)

Nearly the same combinations of eschatological, conspiratorial, and moral expectations can be found in apocalyptic narratives supported and transmitted by various religious groups (whether they were Orthodox, Protestant, or New Age) in post-Soviet states. What factors, however, do shape those narratives as well as their reception or target groups?

It seems to me that the studies of present-day conspiratorial cultures and narratives could take into account the concept of emotional communities formulated recently by American historian Barbara Rosenwein. This constructionist idea that, in turn, proceeds from the theory of textual communities by another American historian, Brian Stock, implies that we should pay more attention to 
emotions that are expected by a particular community and thus are especially valued by its members. "Emotional communities," wrote Rosenwein, "are largely the same as social communities - families, neighborhoods, syndicates, academic institutions, monasteries, factories, platoons, princely courts. But the researcher looking at them seeks above all to uncover systems of feeling, to establish what these communities (and the individuals within them) define and assess as valuable or harmful to them (for it is about such things that people express emotions); the emotions that they value, devalue, or ignore; the nature of the affective bonds between people that they recognize; and the modes of emotional expression that they expect, encourage, tolerate, and deplore" (Rosenwein 2010: 11). I would not argue that the conspiratorial communities that we are dealing with in the present-day world should be recognized as purely emotional. By and large, conspiracy theories try to make problematic not only socially shared values, but also the status of conventional or official knowledge. I think, however, that conspiracy theories and practices of conspiratorial hermeneutics are inspired by particular combinations of emotional, moral, and epistemological expectations. These shared expectations provide the conspiratorial communities with particular narratives and practices and, on the other hand, allow for combining traditional religious ideas with newly invented conspiratorial ones.

In this context, the legend about the Beast of Brussels as well as similar conspiratorial narratives and themes appear to have enough potential to inspire and even form religious communities that expect to share fears of modern technology and surveillance society, tend to distrust science and social institutions, and feel a need of knowledge that can be easily interpreted in moral terms of good and evil. Although some present-day anthropologists would argue that, epistemologically, "there are no inherent differences" between conspiracy theories and other theories (Pelkmans \& Machold 2011), it seems that in terms of social effect and adaptability conspiratorial narratives that constitute a vast part of contemporary legends should still be set apart. In my opinion, their specific fitness potential is related to unique combinations of emotional, moral, and epistemological expectations, which constitute the very idea of conspiracy and secret power in many present-day societies.

\section{ACKNOWLEDGEMENTS}

The research was supported by a grant from the Russian Science Foundation, project No. 14-18-02952 ("Conspiratorial Narratives in Russian Culture"). 


\section{NOTES}

1 For discussion, criticism, and further reading about the meme theory in general see Aunger 2000. See also recent discussion of the memetic approach in folkloristics by Elliot Oring (2014a, 2014b).

2 I would prefer to use 'Last Times' rather than 'Doomsday' to emphasize that premillenial prophetic imagination deals not only with the Last Judgement as a particular event but with sort of 'histories of the future' as a more complicated set of events.

${ }^{3}$ On philo-Semitic and pro-Zionistic aspects of Evangelical millennialism see Ariel 2011.

${ }^{4}$ I would also mention that there is, so to speak, a false trail here - the skeptical narrative about a Christian author, Joe Musser, who is supposed to have invented the story about the 'Beast' computer for his apocalyptic anti-utopian novel. This version, which has received a wide diffusion on the Internet, has been believed by certain researchers (see, e.g., Lewis 2001: 24; Akhmetova 2010: 147), but I have not been able to find any factual evidence to support it.

5 See https://www.truthorfiction.com/beastofbelgium/, last accessed on July 3, 2017.

6 See her name listed among the former staff members on the website of the newspaper: http://www.nashidni.com/index.php/aboutus-en/our-staff/former-and-current-staffmembers. See also her autobiographical article in another newspaper published by Russian Baptists in Germany (Tayson 1980).

7 See http://www.odigitria.by/2012/06/28/znameniya-vremen-666-starec-paisij-svyatogorec/, last accessed on July 3, 2017.

\section{REFERENCES}

Ageeva, Elena 1997. Staroobriadcheskaia polemika ob antikhriste na iskhode XX v. [Disputes about the Antichrist among Old Believers in the Late 20th Century.] Ural'skii sbornik. [The Ural Collection.] Ekaterinburg: n.p., pp. 9-16. Available at http://elar.urfu.ru/bitstream/10995/21345/1/us1997-02.pdf, last accessed on May 12, 2017.

Akhmetova, Maria 2010. Konets sveta v odnoi otdel'no vziatoi strane: religioznye soobshchestva postsovetskoi Rossii $i$ ikh eskhatologicheskii mif. [The Apocalypses in One Particular Country: Religious Communities of Post-Soviet Russia and Their Eschatological Myth.] Moscow: RGGU.

Aleksandrov, Evgeniy 2005. Russkie v Severnoi Amerike: Biograficheskii slovar'. [Russians in North America: A Biographical Dictionary.] St. Petersburg: SPb State University Press.

Ariel, Yaakov 2011. "It's All in the Bible": Evangelical Christians, Biblical Literalism, and Philosemitism in Our Times. In: J. Karp \& A. Sutcliffe (eds.) Philosemitism in History. Cambridge: Cambridge University Press, pp. 257-285.

Aunger, Robert (ed.) 2000. Darwinizing Culture: The Status of Memetics as a Science. Oxford: Oxford University Press. 
Bainbridge, William Sims 1993. New Religions, Science, and Secularization. In: D. G. Bromley \& J. K. Hadden (eds.) Religion and the Social Order: The Handbook on Cults and Sects in America, Vol. 3, Part A. Greenwich, CT \& London: JAI Press Inc., pp. 277-292.

Barkun, Michael 2003. A Culture of Conspiracy: Apocalyptic Visions in Contemporary America. Berkeley \& Los Angeles \& London: University of California Press.

Beglov, Aleksei 2014. Eschatological Expectations in Post-Soviet Russia: Historical Context and Modes of Interpretation. In: K. Tolstaya (ed.) Orthodox Paradoxes: Heterogeneities and Complexities in Contemporary Russian Orthodoxy. Leiden: Brill, pp. 106-133.

Berger, Peter L. (ed.) 1999. The Desecularization of the World: Resurgent Religion and World Politics. Grand Rapids, MI: William B. Eerdmans.

Birchall, Clare 2006. Knowledge Goes Pop: From Conspiracy Theory to Gossip. Oxford $\&$ New York: Berg.

Boyer, Pascal 2001. Religion Explained. The Human Instincts That Fashion Gods, Spirits and Ancestors. New York: Basic Books.

Boyer, Paul 1992. When Time Shall Be No More: Prophecy Belief in Modern American Culture. Cambridge, Mass.: Belknap Press.

Cantelon, Willard 1973. The Day the Dollar Dies. Plainfield, NJ: Logos International.

Cohn, Norman 2005 [1973]. Europe's Inner Demons: The Demonization of Christians in Medieval Christendom. London: Pimlico.

Evans-Pritchard, Edward 1976. Witchcraft, Oracles, and Magic among the Azande. Oxford: Oxford University Press.

Fenster, Mark 2008 [1999]. Conspiracy Theories: Secrecy and Power in American Culture. Revised and Updated Edition. Minneapolis \& London: University of Minnesota Press.

Foster, George M. 1965. Peasant Society and the Image of Limited Good. American Anthropologist, Vol. 67, No. 2, pp. 293-315. http://dx.doi.org/10.1525/ aa.1965.67.2.02a00010.

Fomin, Sergey 1991. "Chitaiushchii da razumeet..." (Prorochestva o sud'bakh Rossii). Prorochestva o sud'bakh Rossii) [“Let the Reader Understand...”: Prophecies about the Destiny of Russia.] Nash sovremennik, No. 9, pp. 120-129.

Frankfurter, David 2006. Evil Incarnate: Rumors of Demonic Conspiracy and Satanic Abuse in History. Princeton: Princeton University Press.

Fuller, Robert C. 1995. Naming the Antichrist: The History of an American Obsession. New York \& Oxford: Oxford University Press.

Gorski, Philip S. \& Kim, David Kyuman \& Torpey, John \& VanAntwerpen, Jonathan (eds.) 2012. The Post-Secular in Question: Religion in Contemporary Society. New York \& London: New York University Press.

Habermas, Jurgen 2006. Religion in the Public Sphere. European Journal of Philosophy, Vol. 14, No. 1, pp. 1-25. http://dx.doi.org/10.1111/j.1468-0378.2006.00241.x.

Heath, Chip \& Bell, Chris \& Sternberg, Emily 2001. Emotional Selection in Memes: The Case of Urban Legends. Journal of Personality and Social Psychology, Vol. 81, No. 6, pp. 1028-1041. http://dx.doi.org/10.1037/0022-3514.81.6.1028.

Hofstadter, Richard 1965 [1952]. The Paranoid Style in American Politics and Other Essays. New York: Knopf. 
Karpov, Vyacheslav 2010. Desecularization: A Conceptual Framework. Journal of Church and State, Vol. 52, No. 2, pp. 232-270. http://dx.doi.org/10.1093/jcs/csq058.

Knight, Peter 2000. Conspiracy Culture: From the Kennedy Assassination to The X-Files. New York \& London: Routledge.

Lewis, James R. 2001. Satanism Today: An Encyclopedia of Religion, Folklore, and Popular Culture. Santa Barbara \& Denver \& Oxford: ABC-CLIO.

Lyon, David 1994. The Electronic Eye: The Rise of Surveillance Society. Minneapolis: University of Minnesota Press.

Marcus, George E. (ed.) 1999. Paranoia within Reason: A Casebook on Conspiracy as Explanation. Chicago \& London: The University of Chicago Press.

Meletiy 2001 = Meletii, Mitropolit Nikopol'skii. Pechat' antikhrista v pravoslavnom predanii. [The Imprint of the Antichrist in the Orthodox Tradition.] Transl. from Modern Greek. Moscow: Izdatel'stvo sestrichestvo vo imia prepodobnomuchenitsy velikoi kniagini Elizavety. Available at http://www.wco.ru/biblio/books/meletn2/ main.htm, last accessed on May 12, 2017.

Molokotos-Liederman, Lina 2003. Identity Crisis: Greece, Orthodoxy, and the European Union. Journal of Contemporary Religion, Vol. 18, No. 3, pp. 291-314. http:// dx.doi.org/10.1080/13537900310001601677.

Moore, Robert I. 2007 [1987]. The Formation of a Persecuting Society: Authority and Deviance in Western Europe 950-1250. Oxford: Blackwell.

Oring, Elliott 2014a. Memetics and Folkloristics: The Theory. Western Folklore, Vol. 73, No. 4, pp. 432-454. Available at https://www.questia.com/library/ journal/1P3-3636001441/memetics-and-folkloristics-the-theory, last accessed on May 12, 2017.

Oring, Elliott 2014b. Memetics and Folkloristics: The Applications. Western Folklore, Vol. 73, No. 4, pp. 455-492. Available at https://www.questia.com/library/ journal/1P3-3636001451/memetics-and-folkloristics-the-applications, last accessed on May 12, 2017.

Pelkmans, Mathijs \& Machold, Rhys 2011. Conspiracy Theories and Their Truth Trajectories. Focaal: Journal of Global and Historical Anthropology, Vol. 59, pp. 66-80. http://dx.doi.org/10.3167/fcl.2011.590105.

Pipes, Daniel 1997. Conspiracy: How the Paranoid Style Flourishes and Where It Comes From. New York: Free Press.

Pokrovskiy \& Zolnikova 2002 = Pokrovskii, Nikolai \& Zol'nikova, Natalia. Staroverychasovennye na Vostoke Rossii XVIII-XX vv.: Problemy tvorchestva i obshchestvennogo soznaniia. [The Chasovennye Old Believers in the East of Russia from the 18th to the 20th Centuries: Aspects of Cultural Heritage and Social Imagination.] Moscow: Pamiatniki istoricheskoi mysli.

Popper, Karl Raimund 1962. Conjectures and Refutations: The Growth of Scientific Knowledge. New York \& London: Basic Books.

Popper, Karl Raimund 1966 [1962]. The Open Society and Its Enemies. Vol. 2. The High Tide of Prophecy: Hegel, Marx and the Aftermath. 5th rev. London \& Henley: Routledge.

Relfe, Mary Stewart 1981. When Your Money Fails: The 666 System Is Here. Montgomery, AL: Ministries, Inc. 
Relfe, Mary Stewart 1982. The New Money System 666. Montgomery, AL: Ministries, Inc. Rosenwein, Barbara H. 2010. Problems and Methods in the History of Emotions. Passions in Context, Vol. 1, No. 1, pp. 1-32. Available at http://www.passionsincontext.de/ uploads/media/01_Rosenwein.pdf, last accessed on May 12, 2017.

Rothstein, Mikael 2004. Science and Religion in the New Religions. In: James R. Lewis (ed.) The Oxford Handbook of New Religious Movements. Oxford: Oxford University Press, pp. 99-118.

Russele, Kati 2015. Religiia i sovremennye tekhnologii, ili Protivorechivoe mirovozzrenie pravoslavnykh khristian. [Religion and Modern Technologies, or the Contradictions of the Orthodox Worldview.] In: Zhanna Kormina \& Aleksander Panchenko \& Sergei Shtyrkov (eds.) Izobretenie religii: desekuliarizatsiia v postsovetskom kontekste. [Invention of Religion: Desecularization in Post-Soviet Context.] St. Petersburg: Izdatel'stvo Evropeiskogo universiteta v Sankt-Peterburge, pp. 46-62.

Serzhantov, Pavel 2007-2008. Pravoslavie i kharizmatizm. [Orthodoxy and Charismatic Christianity.] Al'fa i Omega, No. 49, pp. 148-168; No. 50, pp. 116-152; No. 51, pp. 113-144. Available at http://www.pravmir.ru/alfa-i-omega/, last accessed on May 12, 2017.

Shuck, Glen W. 2005. Marks of the Beast: The Left Behind Novels and the Struggle for Evangelical Identity. New York \& London: New York University Press.

Soboleva, Larisa 1997. Amerikanskoe sochinenie ob Antikhriste - komp’iutere v interpretatsii ural'skogo starovera. [An American Essay on the Computer-Antichrist Interpreted by an Old Believer from the Urals.] In: T. Volklova et al. (eds.) Issledovaniia po istorii knizhnoi i traditsionnoi narodnoi kul'tury Severa. [Studies in the History of Literary and Popular Culture of the North.] Syktyvkar: Izd-vo Syktyvkar. un-ta, pp. 118-130.

Stanton, Don E. 1977. Mystery 666. Secunderabad, India: Maranatha Revival Crusade. Tayson 1980 = Taison, Vera. Prezhde i teper'. [Then and Now.] Vera $i$ Zhizn', No. 29, pp. 25-26. Available at http://www.lio.ru/files/images/magazines/vera/ attachments/vera-1980-2.pdf, last accessed on July 3, 2017.

[Tayson V.] 1989. Vsemirnyi zagovor: Chislo 666. [A Global Conspiracy: The Number 666.] Put'spaseniia. Nezavisimyi dukhovno-prosvetitel'nyi al'manakh drevlepravoslavnykh russkikh khristian $v$ rasseianii sushchikh, No. 3, pp. 13-16.

Tayson 1993 = Taison, V. Taina sataninskogo chisla "666". [The Secret of the Satanic Number 666.] Sochi: Khristianin i Vremia.

[Vaulin, Pavel R.] 1981. Nastuplenie zveria. [The Attack of the Beast.] Niva: Illustrirovannyi zhurnal literatury $i$ sovremennoi zhizni, Vol. 9, No. 45, pp. 3-6.

Verkhovskiy 2003 = Verkhovskii, Aleksandr. Politicheskoe pravoslavie: Russkie pravoslavnye natsionalisty $i$ fundamentalisty, 1995-2001 gg. [Political Orthodoxy: Russian Orthodox Nationalists and Fundamentalists in 1995-2001.] Moscow: Tsentr "Sova".

Webber, David F. \& Hutchings, Noah 1978. The Computers Are Coming. Oklahoma City: Southwest Radio Church.

Weber, Max 1989. Science as a Vocation. In: Peter Lassman \& Irving Velody \& Herminio Martins (eds.) Max Weber's 'Science as a Vocation'. London: Unwin Hyman Inc., pp. 3-32. 
West, Harry G. \& Sanders, Todd (eds.) 2003. Transparency and Conspiracy: Ethnographies of Suspicion on the New World Order. Durham \& London: Duke University Press.

Wood, Gordon S. 1982. Conspiracy and the Paranoid Style: Causality and Deceit in the Eighteenth Century. The William and Mary Quarterly, Vol. 39, No. 3, pp. 401-441. http://dx.doi.org/10.2307/1919580. 